\title{
Good corporate governance, Pengungkapan Sustainability Report dan Manajemen Laba Terhadap Nilai Perusahaan
}

\author{
Maria Dwi Putri Jemunu, Gaguk Apriyanto, dan Parawiyati
}

Program Pascasarjana Universitas Merdeka Malang

Jl. Terusan Raya Dieng No. 57 Malang, 65145, Indonesia

\section{Info Artikel}

Keywords:

Firm Value; Good corporate governance; Audit Committee; independent commissioner; Sustainability report Disclosure; and Earning Management.

Kata Kunci:

Good Corporate Governance: Komisaris Independen; Komite Audit; Manajemen laba; Pengungkapan sustainability report; dan Nilai Perusahaan

ISSN (print): 2598-7763 ISSN (online): 2598-7771

\footnotetext{
$\triangle$ Corresponding Author:

Maria Dwi Putri Jemunu: Tel. /Fax. +62 853-3766-7868 E-mail: mariadwiputrijemunu@gmail.com
}

\begin{abstract}
Abtract
This study aims to examine and provide empirical evidence of the impact of good corporate governance and sustainability report disclosure on firm value with earning management as an intervening variable. The firm value measured by price to book value, good corporate governance measured by meeting frequency of audit committee and percentage of the independent commissioner on board, sustainability report disclosure measured by the number of items disclosed divided by the items regulated in the GRI, earning management measured by discretionary accruals. The sampling technique is purposive sampling. The number of samples used in this study is 42 companies listed on the Indonesia Stock Exchange in 2018-2019. The data are analyzed using path analysis. The results showed that the audit committee has a significant influence on earning management. Sustainability report disclosure and the independent commissioner have no significance to the earning management. Sustainability report disclosure and the independent commissioner have a significant influence on firm value. Audit committee and earning management have no significant influence on firm value. Earnings management does not mediate the relationship between audit committee, independent commissioners, and sustainability report disclosure on firm value.
\end{abstract}

Citation: Jemunu, D.P.M., Aprianto, G dan Parawiyati (2020). Good corporate governance, Pengungkapan Sustainability Report dan Manajemen Laba Terhadap Nilai Perusahaan. AFRE Accounting and Financial Review. 3(2): 93-102

\begin{abstract}
Abstraks
Penelitian ini bertujuan untuk menganalisis dan menguji pengaruh good corporate governance dan pengungkapan sustainability report pada nilai perusahaan melalui manajemen laba. Alat ukur nilai perusahaan yaitu Price to Book Value (PBV), good corporate governance menggunakan jumlah rapat komite audit serta persentase dewan komisaris indepeden, pengungkapan sustainability report menggunakan jumlah item yang diungkap dibagi standar GRI, dan manajemen laba menggunakan discretionary accruals. Teknik pengambilan sampel yang digunakan adalah purposive sampling method. Jumlah sampel yang memenuhi kriteria sebanyak 42 perusahaan yang terdaftar di Bursa Efek Indonesia pada tahun 2018 dan 2019. Teknik analisis data yang digunakan adalah analisi jalur. Hasil penelitian menunjukkan komite audit berpengaruh terhadap manajemen laba, sedangkan pengungkapan sustainability report dan dewan komisaris independen tidak berpengaruh terhadap manajemen laba. Pengungkapan sustainability report dan dewan komisaris independen berpengaruh terhadap nilai perusahaan, sedangkan komite audit dan manajemen laba tidak berpengaruh terhadap nilai perusahaan. Manajemen laba tidak memediasi hubungan komite audit, dewan komisaris independen dan pengungkapan sustainability report pada nilai perusahaan.
\end{abstract}




\section{PENDAHULUAN}

Pada dasarnya setiap perusahaan berkeinginan agar perusahaannya terus berkembang, mempunyai kinerja keuangan yang baik serta meningkatkan nilai perusahaan dari waktu ke waktu. Investor mengamati nilai perusahaan melalui harga pasar saham. Nilai perusahaan merupakan persepsi investor terhadap perusahaan yang selalu dikaitkan dengan harga saham (Ramashar \& Hasan, 2018; Haryanto et al., 2018; Ananda, 2018). Nilai perusahaan adalah nilai pasar cerminan dari listing price yang merupakan hasil dari proses penawaran dan permintaan dari perusahaan yang sudah listing di bursa efek (Widyasari, Suhadak, \& Husaini, 2015). Semakin tinggi harga saham perusahaan, semakin tinggi pula nilai perusahaan (Haryanto, 2014; Nazir \& Afza, 2018; Fristiani et al., 2020; dan Firmansyah, Surasni, \& Pancawati, 2020). Nilai perusahaan yang tinggi diikuti dengan kesejahteraan pemegang saham yang meningkat. Kesejahteraan pemegang saham menjadi perhatian manajemen sebagai agen karena manajemen telah diberi kekuasaan untuk peng-ambilan keputusan. Nilai perusahaan yang tinggi akan terwujud apabila perusahaan mampu me-maksimalkan keuntungan serta kinerjanya dan juga memperhatikan kepentingan sosial dan lingkungan.

Teori agensi menjelaskan tentang hubungan antara pihak prinsipal dan agen. Hubungan keagenen serta masalah agensi merupakan dasar yang digunakan untuk memahami good corporate governance (Mukhtaruddin, Relasari, \& Felmania, 2014). Hal ini disebabkan karena fungsi dari penerapan good corporate governance sebagai pengatur hubungan antara prinsipal dengan agen (Renders \& Gaeremynck, 2012; Widyasari, Suhadak, \& Husaini, 2015; Hasan et al., 2018; Kurniawan, 2018; Sari \& Widaninggar, 2020 dan Theresia \& Budi, 2020).

Good corporate governance dalam penelitian ini diproksikan dengan komite audit dan proporsi dewan komisaris independen. Komite audit merupakan komite penunjang dewan komisaris yang bertugas untuk memastikan bahwa laporan keuangan disajikan secara wajar sesuai dengan PABU, memastikan pengendalian internal berjalan dengan baik, memastikan audit internal dan eksternal dilaksanakan sesuai dengan standar audit yang berlaku dan menindak lanjut temuan hasil audit yang dilaksanakan manajemen (KNKG, 2006).

Komisaris independen merupakan komisaris yang berasal dari pihak yang tidak berafiliasi atau tidak mempunyai hubungan bisnis serta kekeluargaan dengan pemegang saham, anggota direksi, juga dengan komisaris lain. Komisaris independen berfungsi sebagai penyelaras dalam proses peng- ambil keputusan guna melindungi hak pemegang saham minoritas serta pihak-pihak yang terkait (Guna \& Herawaty, 2010).

Signalling theory menjelaskan tentang perbedaan perilaku antara dua pihak ketika pihak-pihak tersebut mempunyai akses terhadap informasi (Ilmi, Kustono, \& Sayekti, 2017). Teori ini menjelaskan tentang agen yang menyampaikan sinyal kepada prinsipal. Sinyal tersebut dapat berupa bad news atau good news. Sinyal yang diberikan berupa informasi mengenai tindakan-tindakan manajemen dalam merealisasikan keinginan dari pemegang saham. Contoh sinyal yang tergolong good news atau sinyal positif yang diberikan perusahaan adalah sustainability report atau laporan Corporate Social Responsibility (CSR).

Pengungkapan tanggung jawab lingkungan dan sosial perusahaan merupakan sebuah bentuk tanggung jawab perusahaan serta bentuk komunikasi kepada para pemegang saham dan masyarakat, bahwa perusahaan selain melakukan kegiatan operasional yang menghasilkan laba juga berperan dalam pemeliharaan lingkungan serta pemberdayaan sumber daya manusia. Salah satu manfaat dari sustainability report menurut Suryono \& Prastiwi (2011) adalah menarik perhatian para pemegang saham serta untuk meningkatkan nilai perusahaan. Sustainability report digunakan oleh perusahaan sebagai salah satu keunggulan kompetitif. Perusahaan dengan informasi mengenai tanggung jawab lingkungan dan sosial akan direspon positif oleh investor ditunjukan melalui peningkatan harga saham. Peningkatan harga saham mengakibatkan nilai perusahaan juga meningkat. Penelitian Sabatini \& Sudana (2019) menunjukan bahwa tanggung jawab sosial dan lingkungan perusahaan berpengaruh negatif terhadap nilai perusahaan.

Manajemen perusahaan berusaha untuk memaksimalkan kepentingannya dengan menyajikan informasi laba yang sebaik mungkin dengan alasan akan diperolehnya kompensasi keuangan. Tindakan ini disebut dengan manajemen laba (earning management). Manajemen melakukan manajemen laba dengan tujuan menarik perhatian para pemegang saham akan prestasi kinerja perusahaan yang baik. Ketertarikan investor pada perusahaan tersebut berpengaruh pada harga saham perusahaan dan akhirnya berpengaruh pada nilai perusahaan. Penelitian Lestari \& Ningrum (2018) menunjukan bahwa manajemen laba tidak berpengaruh terhadap nilai perusahaan

Tujuan penelitian untuk: 1) menganalisis pengaruh komite audit, pengungkapan sustainability report dan dewan komisaris independen terhadap manajemen laba, 2) menganalisis pengaruh komite audit, pengungkapan sustainability report, dewan 
komisaris independen, dan manajemen laba terhadap nilai perusahaan, 3) menganalisis pengaruh komite audit, pengungkapan sustainability report dan dewan komisaris independen terhadap nilai perusahaan melalui manajemen laba.

\section{PENGEMBANGAN HIPOTESIS}

\section{Hubungan Komite Audit Terhadap Manajemen} Laba

Perusahaan dengan komite audit diduga dapat mengawasi perilaku manajemen, salah satunya manajemen laba (Sari, Astuti, \& Suseno, 2017). Jumlah pertemuan yang dilakukan oleh komite audit mampu mencegah perilaku manajemen laba karena komite audit mempunyai lebih banyak kesempatan untuk melakukan evaluasi terhadap manajemen. Hal tersebut membuat manajemen tidak mempunyai celah untuk melakukan manajemen laba. Penelitian Lin et al. (2006); Klein (2006); Jao \& Pagalung (2011); Dwiyanti \& Astriena, (2018) menunjukan bahwa komite audit berpengaruh negatif terhadap manajemen laba.

$\mathrm{H}_{1}$ : Komite audit berpengaruh negatif terhadap manajemen laba

\section{Hubungan Sustainability report terhadap Manaje- men Laba}

Perusahaan dengan tingkat pengungkapan sustainability report yang tinggi akan jarang melakukan praktik manajemen laba. Ketika sebuah perusahaan menerbitkan sustainability report, perusahaan tersebut akan memperoleh citra atau penilaian yang baik dari masyarakat luas. Citra yang baik tersebut tidak mudah didapatkan, oleh karena itu manajer akan berperilaku etis sesuai dengan ketentuan yang berlaku. Manajer juga akan lebih berhati-hati dan menghindari praktik kecurangan ataupun manipulasi seperti manajemen laba. Penelitian Ricardo \& Faisal (2015) menunjukan bahwa pengungkapan sustainability report berpengaruh negatif terhadap manajemen laba.

$\mathrm{H}_{2}$ : Pengungkapan sustainability report berpengaruh negatif terhadap manajemen laba

\section{Hubungan Dewan Komisaris Independen Terha- dap Manajemen Laba}

Komisaris independen berfungsi sebagai pemberi saran dan masukan dalam rangka pencapaian tujuan perusahaan (Guna \& Herawaty, 2010; Kumaat, 2013; Agustia, 2013; (Rahmawati, 2013); dan Sari, 2016). Komisaris indepen-den melakukan tindakan pengawasan kepada peru-sahaan dalam rangka penerapan tata kelola yang baik. Perusahaan dengan proporsi dewan komisaris independen yang meningkat dapat mengurangi tin-dakan manajemen laba yang dilakukan manajemen.

$\mathrm{H}_{3}$ : Dewan komisaris independen berpengaruh negatif terhadap manajemen laba

\section{Hubungan Komite Audit Terhadap Nilai Peru- sahaan}

Keberadaan komite audit dapat mening-katkan efektifitas kinerja perusahaan. Dengan adanya komite audit, maka perusahaan dapat menghasilkan laporan keuangan yang bebas dari salah saji material yang dapat menyesatkan pengguna laporan keuangan dalam mengambil keputusan. Laporan keuangan yang baik serta diiringi dengan kinerja keuangan yang baik, dapat mendorong investor untuk membeli saham perusahaan. Harga saham yang meningkat membuat nilai perusahaan juga meningkat. Penelitian Widyasari, Suhadak, \& Husaini (2015) menunjukan bahwa komite audit berpengaruh positif terhadap nilai perusahaan.

$\mathrm{H}_{4}$ : Komite audit berpengaruh positif terhadap nilai perusahaan.

\section{Hubungan Sustainability report terhadap Nilai Perusahaan}

Seringkali perusahaan menggunakan sustainability report sebagai alat untuk meningkatkan reputasi perusahaan, sehingga akan berimbas pada meningkatnya nilai perusahaan. Salah satu tujuan diterbitkannya sustainability report adalah untuk menarik perhatian investor agar membeli saham perusahaan. Jika banyak investor yang tertarik untuk membeli saham, maka jumlah saham beredar akan semakin banyak, dan harga saham akan meningkat diiringi dengan meningkatnya nilai perusahaan. Penelitian Latifah \& Luhur (2017) menunjukan adanya pengaruh positif antara pengungkapan sustainability report dengan nilai perusahaan.

$\mathrm{H}_{5}$ : Pengungkapan sustainability report berpengaruh positif terhadap nilai perusahaan.

\section{Hubungan Dewan Komisaris Independen Terha- dap Nilai Perusahaan}

Kepentingan manajemen dan pemegang saham diselaraskan dengan adanya dewan komisaris independen, karena dewan komisaris independen mewakili pihak eksternal untuk memonitor perilaku manajemen yang mengabaikan kepentingan jangka panjang (Prastuti \& Budiasih, 2015). Dengan adanya keselarasan antara manajemen dan pemegang saham, maka manajemen dapat melakukan kegiatan operasional perusahaan dengan baik, sehingga dapat meningkatkan kinerja perusahan seiring dengan meningkatnya nilai perusahaan. Penelitian Murwaningsari (2007) menunjukan adanya penga- 
ruh pengaruh positif antara proporsi dewan komisaris independen terhadap nilai perusahaan.

$\mathrm{H}_{6}$ : Dewan komisaris independen berpengaruh positif terhadap nilai perusahaan.

\section{Hubungan Manajemen Laba Terhadap Nilai Perusahaan}

Tindakan manjemen laba mengakibatkan laporan keuangan yang disajikan tidak meng-gambarkan keadaan yang sesungguhnya terjadi dalam perusahaan. Tindakan manajemen laba berpengaruh pada perubahan harga saham peru-sahaan (Lesmana \& Sukartha, 2017, dan Nekhili et al., 2017). Perubahan harga saham berpengaruh pada nilai perusahaan. Nilai perusahaan yang meningkat terjadi pada periode tertentu saat dilakukannya manajemen laba, namun di masa yang akan datang akan menu-runkan nilai perusahaan (Darwis, 2012). Penelitian yang dilakukan Susanto dan Christiawan (2016) menunjukan bahwa manajemen laba berpengaruh positif terhadap nilai perusahaan.

$\mathrm{H}_{7}$ : Manajemen Laba berpengaruh positif terhadap nilai perusahaan

\section{Hubungan Komite Audit Terhadap Nilai Peru- sahaan Melalui Manajemen Laba}

Semakin banyak pertemuan yang dilakukan oleh komite audit maka keefektifan kegiatan pengawasan terhadap laporan keuangan juga akan meningkat. Meningkatnya pengawasan yang dilakukan oleh komite audit dapat membuat manajemen tidak melakukan manajemen laba. Apabila manajemen melakukan manajemen laba, maka hal ini berdampak pada nilai perusahaan dalam jangka perusahaan.

$\mathrm{H}_{8}$ : Manajemen laba memediasi komite audit terhadap nilai perusahaan secara negatif.

Hubungan Pengungkapan Sustainability report terhadap Nilai Perusahaan Melalui Manajemen Laba

Untuk melakukan kegiatan tanggung jawab sosial dan lingkungan, perusahaan harus mengeluarkan biaya. Untuk menghindari dampak negatif dari adanya tanggung jawab sosial dan lingkungan, maka perusahaan melakukan praktik manajemen laba (Ardianto, 2012). Praktik manajemen laba yang dilakukan akan berdampak pada nilai perusahaan dalam jangka panjang. Perusahaan dengan tingkat pengungkapan sustainability report yang rendah cenderung untuk melakukan praktik manajemen laba yang dapat mengurangi laba yang dilaporkan (Ardianto, 2012).

H9: Manajemen laba memediasi pengungkapan sustainability report terhadap nilai perusahaan secara negatif

\section{Hubungan Dewan Komisaris Independen Terhadap Nilai Perusahaan Melalui Manajemen Laba}

Proporsi dewan komisaris independen yang tinggi dapat memonitor dengan lebih baik perilaku manajemen, sehingga dalam melaksanakan tugasnya terjadi keselarasan antara kepentingan pemegang saham dan manajemen. Tingginya proporsi dewan komisaris independen membuat perusahaan tidak melakukan manajemen laba, sehingga nilai perusahaan dapat meningkat.

$\mathrm{H}_{10}$ : Manajemen laba memediasi dewan komisaris independen terhadap nilai perusahaan secara negatif.

\section{METODE PENELITIAN}

Jenis data yang digunakan dalam penelitian ini adalah data runtun waktu (time series). Penelitian ini menggunakan data runtun waktu tahunan, yaitu dua tahun selama tahun 2018 dan 2019. Berdasarkan bentuk atau karakteristik data, penelitian ini menggunakan data kuantitatif dan data kualitatif. Data kuantitatif yang digunakan berupa laporan laba rugi, neraca, sedangkan data kualitatif yang digunakan berupa sustainability report.

Berdasarkan sumber pengumpulan data, data yang digunakan dalam penelitian ini merupakan data sekunder. Data penelitian bersumber dari Bursa Efek Indonesia (BEI). Data sekunder dikumpulkan dengan dengan teknik dokumentasi. Teknik penarikan sampel yang digunakan adalah dengan metode penyampelan nonprobabilitas (nonprobability sampling) yaitu dengan purposive sampling dengan kriteria 1) Perusahaan yang terdaftar di Bursa Efek Indonesia pada tahun 2018 dan 2019, 2) Perusahaan yang menerbitkan sustainability report selama periode pengamatan tahun 2018 dan 2019, 3) Perusahaan yang menyajikan informasi sesuai dengan yang dibutuhkan dalam penelitian selama periode pengamatan tahun 2018 dan 2019. Jumlah sampel 42 perusahaan dengan 84 pengamatan.

Nilai perusahaan diukur dengan menggunakan price to book value, yang diperoleh dari harga pasar perlembar saham dibagi nilai buku perlembar saham. Komite audit diperoleh dari jumlah rapat yang dilakukan oleh komite audit dibagi 4. Pengungkapan sustainability report diperoleh dari jumlah item yang diungkapkan dibagi standar GRI. Proporsi dewan komisaris independen dihitung dengan cara menjumlah dewan komisaris independen yang ada dalam perusahaan lalu dibagi dengan jumlah dewan komisaris dalam perusahaan. Manajemen laba diukur dengan menggunakan dicretionary accruals. Teknik analisis data menggunakan analisis jalur (path analysis). 


\section{HASIL PENELITIAN}

\section{Statistik Deskriptif}

Hasil analisis deskripsi data disajikan pada

tabel 1. Berdasarkan hasil analisis menunjukkan bahwa varian dari Dewan Komisaris Independen cukup tinggi. Demkian juga dengan varian manajemen laba perusahaan lebih tinggi dari rata.

Tabel 1. Statistik Deskriptif

\begin{tabular}{lrrrr}
\hline Variabel & Minimum & Maksimum & Rerata & Std. Deviation \\
\hline Komite Audit $\left(\mathrm{X}_{1}\right)$ & 0,75 & 11,50 & 3,18 & 2,32 \\
Pengungkapan SR $\left(\mathrm{X}_{2}\right)$ & 0,17 & 0,89 & 0,43 & 1,12 \\
Dewan Komisaris Independen $\left(\mathrm{X}_{3}\right)$ & 16,67 & 83,33 & 44,06 & 11,85 \\
Manajemen Laba $(\mathrm{Y})$ & $-0,23$ & 1,58 & $-0,00$ & 0,24 \\
Nilai Perusahaan $(\mathrm{Z})$ & 0,01 & 6,07 & 1,31 & 1,29 \\
\hline
\end{tabular}

Hasil uji asumsi klasik menunjukan bahwa 1) penelitian ini bebas dari masalah normalitas (nilai Asymp. Sig. (2-tailed) 0,107 lebih besar dari $0,05)$, 2)variabel-variabel dalam penelitian ini tidak berhubungan satu sama lain, atau dengan kata lain data penelitian ini tidak terdapat masalah multikolinearitas (ditunjukan oleh nilai VIF $<10,00$ dan tolerance $>0,10)$, 3) tidak terdapat gejala autokorelasi dalam penelitian ini (ditun-

$0,05), 4)$ tidak terdapat masalah heterokedastisitas dalam penelitian ini (ditunjukan oleh nilai signifikansi dari tiap variabel lebih besar dari 0,05).

Hasil analisis dan pengujian hipotesis dapat dilihat pada tabel 2. Berdasarkan hasil analisis menunjukkan bahwa Komite Audit berpengaruh terhadap manajemen laba. Sedangkan Pengungkapan sustainability report dan Dewan Komisaris Independent tidak berpengaruh terhadap manajemen laba. jukkan dengan nilai sig 0,380 lebih besar dari

Tabel 2. Hasil Pengujian Hipotesis

\begin{tabular}{|c|c|c|c|c|c|c|c|}
\hline & B & Sig. & $\mathrm{R}^{2}$ & Keterangan & $\begin{array}{l}\text { Pengaruh } \\
\text { Tidak } \\
\text { langsung }\end{array}$ & $\rho$-value & Kesimpulan \\
\hline$X_{1}->Y$ & 0,263 & 0,016 & & Berpengaruh Signifikan & - & - & $\mathrm{H}_{1}$ Ditolak \\
\hline$X_{2}->Y$ & $\begin{array}{c}- \\
0,113\end{array}$ & 0,296 & $10,9 \%$ & $\begin{array}{l}\text { Tidak Berpengaruh } \\
\text { Signifikan }\end{array}$ & - & - & $\mathrm{H}_{2}$ Ditolak \\
\hline$X_{3}->Y$ & 0,174 & 0,106 & & $\begin{array}{c}\text { Tidak Berpengaruh } \\
\text { Signifikan }\end{array}$ & - & - & $\mathrm{H}_{3}$ Ditolak \\
\hline$X_{1}->Z$ & 0,008 & 0,940 & & $\begin{array}{l}\text { Tidak Berpengaruh } \\
\text { Signifikan }\end{array}$ & 0,020 & 0,984 & $\mathrm{H}_{4} \& \mathrm{H}_{8}$ Ditolak \\
\hline$X_{2}->Z$ & $\begin{array}{c}- \\
0,260\end{array}$ & 0,013 & & Berpengaruh Signifikan & $-0,372$ & 0,711 & $\mathrm{H}_{5} \& \mathrm{H}_{9}$ Ditolak \\
\hline$x_{3}->Z$ & 0,373 & 0,000 & $22 \%$ & Berpengaruh Signifikan & 0,004 & 0,997 & $\begin{array}{c}\mathrm{H}_{6} \text { Diterima \& } \mathrm{H}_{10} \\
\text { Ditolak }\end{array}$ \\
\hline$Y->Z$ & $\begin{array}{c}- \\
0,119\end{array}$ & 0,260 & & $\begin{array}{c}\text { Tidak Berpengaruh } \\
\text { Signifikan }\end{array}$ & - & - & $\mathrm{H}_{7}$ Ditolak \\
\hline
\end{tabular}

\section{PEMBAHASAN}

\section{Komite Audit Terhadap Manajemen Laba}

Hasil penelitian ini menunjukan bahwa semakin tinggi frekuensi rapat komite audit semakin tinggi pula tingkat manajemen laba yang dilakukan perusahaan. Jumlah rapat komite audit yang banyak tidak menjamin efektifitas pengawasan yang dilaksanakan oleh komite audit, sehingga manajemen memiliki celah untuk melakukan tindakan manajemen laba. Tingginya frekuensi rapat komite audit menunjukan fungsi komite audit yang tidak efektif, misalnya rapat yang singkat sehingga masalah tidak terselesai- kan dengan baik (Albersmann \& Hohenfels, 2017). Jensen (1993) dalam Gosh (2010) mengatakan bahwa komite audit memperbanyak jumlah rapat jika komite sedang berhadapan dengan masalah. Jadi, rapat komite audit diadakan sebagai solusi untuk masalah akuntansi bukan sebagai tindakan proaktif untuk mencegah masalah itu sendiri. rapat yang tinggi dapat diikuti dengan meningkatnya manajemen laba jika anggota komite audit dalam suatu perusahaan yang berlatar belakang akuntansi dan keuangan hanya dimiliki oleh sedikit orang. Hasil penelitian ini tidak konsisten dengan hasil penelitian Wulanda \& Aziza (2019) yang menemukan bahwa komite audit tidak berpengaruh terhadap manajemen laba. 
Pengungkapan Sustainability report Terhadap Manajemen Laba

Hasil penelitian ini menunjukan bahwa pengungkapan sustainability report tidak berpengaruh terhadap manajemen laba. Penelitian ini didukung oleh penelitian Arief \& Ardiyanto (2014) yang menemukan bahwa tidak ada pengaruh pengungkapan tanggung jawab sosial dan lingkungan terhadap manajemen laba. Tinggi atau rendahnya tingkat pengungkapan sustainability report tidak mempengaruhi manajemen dalam melakukan manajemen laba. Tingginya tingkat pengungkapan sustainability report tidak menjamin perusahaan untuk meminimalisir tindakan manajemen laba. Saat perusahaan menerbitkan sustainability report, perusahaan akan memperoleh gambaran atau citra yang baik dari masyarakat luas, namun disisi lain kegiatankegiatan yang diungkapkan dalam sustainability report tersebut membutuhkan banyak biaya. Citra baik yang diterima perusahaan dapat memberikan respon positif kepada investor, namun manajemen mengkhawatirkan dengan banyaknya biaya yang dikeluarkan membuat investor tidak tertarik untuk berinvestasi pada perusahaan. Oleh karena itu manajemen memutuskan untuk melakukan manajemen laba. Hasil penelitian ini bertentangan dengan penelitian Prasetya \& Gayatri (2016).

\section{Dewan Komisaris Independen Terhadap Mana- jemen Laba}

Hasil penelitian ini menunjukan bahwa dewan komisaris independen tidak berpengaruh terhadap manajemen laba. Hasil penelitian ini konsisten dengan temuan penelitian Hidayanti, Widjayanti, \& Paramita (2014). Tinggi atau rendahnya persentase dewan komisaris independen dalam suatu perusahaan tidak mempengaruhi manajemen dalam hal manajemen laba. Hal ini disebabkan karena dewan komisaris tidak diperkenankan untuk mengambil keputusan operasisonal dalam perusahaan, sehingga keputusan mengenai manajemen laba berada pada manajemen. Hasil penelitian ini bertentangan dengan hasil penelitian Jao \& Pagalung (2011) yang menunjukan bahwa dewan komisaris independen berpengaruh terhadap manajemen laba.

\section{Komite Audit terhadap Nilai Perusahaan}

Hasil penelitian ini menunjukan bahwa komite audit tidak berpengaruh signifikan tehadap nilai perusahaan. Hasil penelitian ini konsisten dengan temuan penelitian yang dilakukan oleh Purbopangestu \& Subowo (2014) dan penelitian
Wardoyo \& Veronica (2013). Komite audit yang tidak berpengaruh terhadap nilai perusahaan menunjukan bahwa komite audit kurang optimal dalam melaksanakan tugas, tanggung jawab serta wewenang dari komite audit itu sendiri. Komite audit yang kurang optimal dalam melakukan tugas, tanggung jawab serta wewenangnya dapat membuka peluang bagi manajemen untuk melakukan tindak kecurangan yang dapat membuat turunnya minat investor untuk berinvestasi pada suatu perusahaan. Hal tersebut dapat membuat nilai perusahaan menurun. Hasil penelitian ini bertentangan dengan penelitian yang dilakukan oleh Wulanda \& Azizah (2019) yang menemukan bahwa terdapat pengaruh signifikan antara komite audit dan nilai perusahaan.

\section{Pengungkapan Sustainability report terhadap Nilai Perusahaan}

Hasil penelitian menunjukan bahwa pengungkapan sustainability report berpengaruh negatif dan signifikan terhadap nilai perusahaan. Hasil penelitian ini didukung oleh penelitian Sabatini \& Sudana (2019). Pengungkapan sustainability report berpengaruh negatif dan signifikan terhadap nilai perusahaan disebabkan karena meningkatnya pengeluaran untuk membiayai aktivitas-aktivitas yang berkaitan dengan tanggung jawab ekonomi, sosial dan lingkungan tidak diringi dengan perubahan rasio keuangan lain seperti profitabilitas, leverage, pertumbuhan. Hal ini menyebabkan investor beranggapan bahwa peningkatan pengeluaran tersebut hanya berupa pemborososan sumber daya perusahaan semata. Hasil penelitian ini bertentangan dengan penelitian yang dilakukan Ardimas dan Wardoyo (2014) yang menemukan tidak adanya pengaruh antara pengungkapan sustainability report dengan nilai perusahaan.

\section{Dewan Komisaris Independen terhadap Nilai Perusahan}

Hasil penelitian ini menunjukan bahwa dewan komisaris independen berpengaruh positif dan signifikan terhadap nilai perusahaan. Penelitian ini konsisten dengan temuan penelitian yang dilakukan oleh Purbopangestu \& Subowo (2014). Komisaris independen menyelaraskan kepentingan manajer dan pemegang saham karena dewan komisaris independen merupakan perwakilan dari internal perusahaan untuk mengawasi perilaku yang menyalahgunakan peluang atau keuntungan jangka pendek dan mengabaikan keuntungan jangka panjang (Prastuti \& Budiasih, 2015). Adanya pengaruh antar dewan komisaris independen dengan nilai perusahaan menunjukan bahwa dewan komisaris independen pada perusahaan sampel melakukan pengawasan yang efektif sehingga dengan keberadaannya dapat meningkatkan nilai perusahaan. Hasil penelitian ini bertentangan dengan penelitian 
Suyanti, Rahmawati, \& Aryani (2010) yang menemukan bahwa dewan komisaris independen tidak berpengaruh terhadap nilai perusahaan.

\section{Manajemen Laba Terhadap Nilai Perusahaan}

Hasil penelitian ini menunjukan bahwa ma-najemen laba tidak berpengaruh terhadap nilai perusahaan. Penelitian ini konsisten dengan penelitian Darwis (2012). Penyebab manajemen laba tidak berpengaruh terhadap nilai perusahaan diduga disebabkan karena investor mempunyai pertimbangan utama lain selain laba sebagai alasan untuk berinvestasi pada suatu perusahaan (Wulanda \& Aziza, 2019). Pemakai laporan keuangan beranggapan bahwa laba yang dilaporkan dalam laporan keuangan tidak menunjukkan kinerja manajemen secara keseluruhan, sehingga investor tidak terfokus pada besar atau kecilnya laba yang dihasilkan oleh perusahaan. Hasil penelitian ini bertentangan dengan penelitian Indriani, Darmawan, \& Nurhawa (2014) yang menunjukan adanya pengaruh antara manajemen laba dengan nilai perusahaan.

\section{Komite Audit terhadap Nilai Perusahaan Mela- lui Manajemen Laba}

Hasil penelitian menunjukkan bahwa manajemen laba tidak memediasi hubungan komite audit dengan niai perusahaan. Komite audit dengan frekuensi rapat yang lebih banyak diharapkan dapat membuat fungsi pengawasan komite audit dapat berjalan dengan lebih efektif dan efisien. Namun pengaruh langsung antara komie audit terhadap nilai perusahaan menunjukan bahwa tidak ada pengaruh antara komite audit dengan nilai perushaan. Begitu juga dengan pengaruh tidak langsung komite audit terhadap nilai perusahaan melalui manajemen laba. Hal ini menunjukan bahwa frekuensi rapat yang dilakukan komite audit tidak berpengaruh terhadap nilai perusahaan sekalipun perusahaan tersebut melakukan atau meminimalisir manajemen laba.

Pengungkapan Sustainability report terhadap Nilai Perusahaan Melalui Manajemen Laba

Hasil penelitian menunjukkan bahwa manajemen laba tidak memediasi hubungan pengungkapan sustainability report dengan nilai perusahaan. Tingkat pengungkapan sustainability report suatu perusahaan tidak berpengaruh terhadap nilai perusahaan sekalipun perusahaan tersebut melakukan atau tidak melakukan tindakan manajemen laba. Tingkat pengungkapan sustainability report yang tinggi membuat investor enggan berinvestasi pada suatu perusahaan karena perusahaan yang melakukan aktivitas tang- gung jawab sosial dan lingkungan dianggap melakukan pemborosan sumber daya perusahaan. Hal ini mengakibatkan nilai perusahaan yang menurun. Di sisi lain, manajemen laba tidak mempengaruhi nilai perusahaan. Pemakai laporan keuangan menggangap laba yang tertera dalam laporan keuangan tidak menampilkan kinerja perusahaan secara utuh, oleh karena itu investor mempunyai pertimbangan lain dalam berinvestasi.

\section{Dewan Komisaris Independen Terhadap Nilai Perusahaan Melalui Manajemen Laba}

Hasil penelitian menunjukkan bahwa manajemen laba tidak memediasi hubungan dewan komisaris independen dengan nilai perusahaan. Besarnya persentase dewan komisaris independen dalam suatu perusahaan tidak mempengaruhi nilai perusahaan sekalipun perusahaan tersebut melakukan atau tidak melakukan tindakan manajemen laba. Besarnya persentase dewan komisaris independen dalam suatu perusahaan tidak mempengaruhi nilai perusahaan sekalipun perusahaan tersebut melakukan atau tidak melakukan tindakan manajemen laba. Secara langsung, dewan komisaris independen berpengaruh terhadap nilai perusahaan. Semakin besar persentase dewan komisaris independen dalam perusahaan maka tingkat pengawasan menjadi lebih baik yang menyebabkan nilai perusahaan meningkat. Di sisi lain, manajemen laba tidak berpengaruh terhadap nilai perusahaan. Tinggi atau rendahnya manajemen laba tidak mempengaruhi nilai perusahaan.

\section{SIMPULAN DAN SARAN}

Hasil penelitian menunjukkan komite audit berpengaruh terhadap manajemen laba, sedangkan pengungkapan sustainability report dan dewan komisaris independen tidak berpengaruh terhadap manajemen laba. Pengungkapan sustainability report dan dewan komisaris independen berpengaruh terhadap nilai perusahaan, sedangkan komite audit dan manajemen laba tidak berpengaruh terhadap nilai perusahaan. Manajemen laba tidak memediasi hubungan komite audit, dewan komisaris independen dan pengungkapan sustainability report pada nilai perusahaan.

Keterbatasan dalam penelitian ini antara lain 1) penelitian ini hanya menggunakan periode penelitian 2 tahun yaitu tahun 2018 dan 2019 dengan jumlah sampel 42 dan jumlah observasi 84. Peneliti selanjutnya diharapkan dapat memperpanjang periode penelitian. 2) Hasil penelitian ini menunjukan masih banyak faktor atau variabel-variabel lain yang dapat mempengaruhi nilai perusahaan. Peneliti selanjutnya diharapkan dapat menambah variabel lain seperti menambah indikator good corporate governance yang lain. 


\section{DAFTAR PUSATAKA}

Agustia, D. (2013). Pengaruh Faktor Good Corporate Governance, Free Cash Flow, dan Leverage Terhadap Manajemen Laba. Jurnal Akuntansi Dan Keuangan, 15(1), 27-42. https://doi.org/10.9744/jak.15.1.27-42

Albersmann, B. T., \& Hohenfels, D. (2017). Audit Committees and Earnings Management Evidence from the German Two-Tier Board System. Schmalenbach Bussines Review, 1-32.

Ananda, A. F. (2018). Stuktur Modal, Kinerja Perusahaan, dan Altman Z-Score Pengaruhnya Terhadap Ekspektasi Investor. AFRE (Accounting and Financial Review), 1(1). https://doi.org/10.26905/afr.v1i1. 2285

Ardianto, Y. (2012). Pengaruh Corporate Social Disclosure terhadap Nilai Perusahaan dengan Manajemen Laba Sebagai Variabel Intervening. Akuntabilitas Vol 12 No.1, 104114.

Ardimas, W., \& Wardoyo. (2014). Pengaruh Kinerja Keuangan dan Corporate Social Responsibility Terhadap Nilai Perusahaan Pada Bank Go Public Yang Terdaftar dI BEI. BENEFIT Jurnal Manajemen dan Bisnis, 57-66.

Arief, A., \& Ardiyanto, M. D. (2014). Pengaruh Pengungkapan Corporate Social Responsibility Terhadap Manajemen Laba. Diponegoro Journal Of Accounting, 1-9.

Darwis, H. (2012). Manajemen Laba Terhadap Nilai Perusahaan Dengan Corporate Governance Sebagai Pemoderasi. Keuangan dan Perbankan, Vol.16, No.1, 45-55.

Deegan, C. (2002). The legitimising effect of social and inveronmental disclosure - a theoritical foundation. Accounting, auditing $\mathcal{E}$ acountability journal, vol 15 no 3, 282-311.

Dwiyanti, K. T., \& Astriena, M. (2018). Pengaruh Kepemilikan Keluarga Dan Karakteristik Komite Audit Terhadap Manajemen Laba. Jurnal Riset Akuntansi Dan Bisnis Airlangga, 3(2), 447-469. https://doi.org/10.31093/ jraba. v3i2.123

Fatchan, I. N., \& Trisnawati, R. (2016). Pengaruh Good Corporate Governance Pada Hubungan Antara Sustainability Report Dan Nilai Perusahaan (Studi Empiris Perusahaan Go Public di Indonesia Periode 2014-2015). Riset Akuntansi dan Keuangan Indonesia 1(1), 25-34.

Firmansyah, D., Surasni, N. K., \& Pancawati, S. (2020). Pengaruh CSR Terhadap Nilai Perusahaan Dengan Good Corporate Governance Dan Ukuran Perusahaan
Sebagai Variabel Pemoderasi. E-JA e-Jurnal Akuntansi Vol. 30 No. 1, 163-178.

Freeman, R. E. (1984). Strategic management: A stakeholder approach. Boston: Pitman.

Fristiani, N. L., Pangastuti, D. A., \& Harmono, H. (2020). Intellectual Capital Dan Kinerja Keuangan Terhadap Nilai Perusahaan: Pada Industri Perbankan. AFRE (Accounting and Financial Review), 3(1), 35-42. https://doi.org/ 10.26905/afr.v3i1.4223

Ghosh, A., Marra, A., \& Moon, D. (2010). Corporate Boards, Audit Committees,and Earnings Management: Pre- and Post-SOX Evidence. Journal of Business Finance \& Accounting, 11451176.

Governance, K. N. (2006). Pedoman Umum Good Corporate Governance.

Guna, W. I., \& Herawaty, A. (2010). Pengaruh Mekanisme Good Corporate Governance, Independensi Auditor, Kualitas Audit dan Faktor lainnya Terhadap Manajemen Laba. Jurnal Bisnis dan Akuntansi, Vol. 12, No. 1, 53-68.

Gunawan, Y., \& Mayangsari, S. (2015). Pengaruh Sustainability Reporting Terhadap Nilai Perusahaan Dengan Investment Opportunity Set Sebagai Variabel Moderating. e-Journal Akuntansi Trisakti Volume. 2 Nomor. 1, 1-12.

Haryanto, S. (2014). Identifikasi Ekspektasi Investor Melalui Kebijakan Struktur Modal, Profitabilitas, Ukuran Perusahaan Dan Gcpi. Jurnal Dinamika Manajemen, 5(2), 183-199. https://doi.org/ 10.15294/jdm.v5i2.3660

Haryanto, S., Rahadian, N., Mbapa, M. F. I., Rahayu, E. N., \& Febriyanti, K. V. (2018). Kebijakan Hutang, Ukuran Perusahaan dan Kinerja Keuangan Terhadap Nilai Perusahaan: Industri Perbankan di Indonesia. AFRE (Accounting and Financial Review), 1(2). https://doi.org/10.26905/ afr.v1i2.2279

Hasan, I., Kobeissi, N., Liu, L., \& Wang, H. (2018). Corporate Social Responsibility and Firm Financial Performance: The Mediating Role of Productivity. Journal of Business Ethics, 149(3), 671-688. https://doi.org/10.1007/s10551-0163066-1

Hidayanti, E., \& Paramita, R. W. (2014). Pengaruh Good Corporate Governance Terhadap Praktek Manajemen Laba Riil Pada Perusahaan Manufaktur. Jurnal WIGA, 1-16.

Ilmi, M., Kustono, A. S., \& Sayekti, Y. (2017). Effect Of Good Corporate Governance, Corporate Social Responsibility Disclosure And Managerial Ownership To The Corporate Value With Financialperformance As Intervening Variables: Case On Indonesia Stock Exchange. International 
Journal of Social Science and Business. Vol.1 (2), 75-88.

Indriani, P., Darmawan, J., \& Nurhawa, S. (2014). Analisis Manajemen Laba Terhadap Nilai Perusahaan Yang Terdaftar di Bursa Efek Indonesia. Jurnal Akuntansi \& Keuangan, 1932.

Jao, R., \& Pagalung, G. (2011). Corporate Governance, Ukuran Perusahaan, Dan Leverage Terhadap Manajemen Laba Perusahaan Manufaktur Indonesia. Jurnal Akuntansi \& Auditing Volume 8/No. 1, 43-54.

Klein, A. (2006). Audit Committee, Board of Director Characteristics, and Earnings Management. Law \& Economics Research Paper Series, October. http://www.sciencedirect.com/science/ar ticle/pii/S0165410102000599

Kumaat, L. C. (2013). Corporate Governance dan Struktur Kepemilikan Terhadap Manajemen Laba dan Kinerja Keuangan. Jurnal Keuangan Dan Perbankan, 17(1), 11-20.

Kurniawan, T., Sofyani, H., \& Rahmawati, E. (2018). engungkapan Sustainability Report dan Nilai Perusahan: Studi Empiris di Indonesia dan Singapura. Jurnal Ilmiah Akuntansi, Volume XVI, No 1, 1-20.

Kurniawan, Y. (2018). Indonesia Most Trusted Company dan Nilai Perusahaan. AFRE (Accounting and Financial Review), 1(1), 1-8. https://doi.org/10.26905/afr.v1i1.2267

Latifah, S. W., \& Luhur, M. B. (2017). Pengaruh Pengungkapan Sustainability Report Terhadap Nilai Perusahaan Dengan Profitabilitas Sebagai Pemoderasi. Jurnal Akuntansi dan Bisnis Vol. 17, 13-18.

Lesmana, P. A., \& Sukartha, I. M. (2017). Pengaruh Manajemen Laba Pada Nilai Perusahaan Manufaktur Yang Terdaftar di Bursa Efek Indonesia Tahun 2012-2015. EJurnal Akuntansi Universitas Udayana, 10601087.

Lestari, N., \& Ningrum, S. A. (2018). Pengaruh Manajemen Laba dan Tax Avoidance terhadap Nilai Perusahaan dengan Kualitas Audit sebagai Variabel Moderasi. Journal of Applied Accounting and Taxation, 99-109.

Lin, J. W., Li, J. F., \& Yang, J. S. (2006). The effect of audit committee performance on earnings quality. Managerial Auditing Journal, 21(9), 921-933. https://doi.org/ 10.1108/02686900610705019

Lofgren, K. G., Persson, T., \& Weibull , J. W. (2002). Markets With Aymetric Information : The Contribution Of George Akerlof,
Michael Spence, And Joseph Stiglitz. Scand. J. Of Economics 104(2), 195-211.

Mukhtaruddin, Relasari, \& Felmania, M. (2014). Good Corporate Governance Mechanism, Corporate Social Responsibility Disclosure on Firm Value: Empirical Study on Listed Company in Indonesia Stock Exchange. International Journal of Finance $\mathcal{E}$ Accounting Studies, 1-10.

Murwaningsari, E. (2007). Pengaruh Corporate Governance Terhadap Nilai Perusahaan Dengan Manajemen Laba Sebagai Variabel Intervening. The 1st Accounting Conference (hal. 1-47). Depok: Faculty of Economics Universitas Indonesia.

Nazir, M. S., \& Afza, T. (2018). Does managerial behavior of managing earnings mitigate the relationship between corporate governance and firm value? Evidence from an emerging market. Future Business Journal, 4(1), 139-156. https://doi.org/10.1016/j.fbj.2018.03.001

Nekhili, M., Nagati, H., Chtioui, T., \& Rebolledo, C. (2017). Corporate social responsibility disclosure and market value: Family versus nonfamily firms. Journal of Business Research, 77(March). https://doi.org/10.1016/j.jbusres. 2017.04.001

Oktaviani, R. N., Nur, E., \& Ratnawati, V. (2015). Pengaruh Good Corporate Governanceterhadap Kualitas Laba Dengan Manajemen Laba Sebagai Variabel Intervening (Studi Empiris Pada Perusahaan Manufaktur Yang Terdaftar Di Bursa Efek Indonesia Tahun 2009-2012). Jurnal Ekonomi, Manajemen dan Akutansi I Vol. 25 No. 2, 97-115.

Rahmawati, H. I. (2013). Pengaruh Good Corporate Governance (GCG) Terhadap Manajemen Laba Pada Perusahaan Perbankan. Accounting Analysis Journal, 2(1). https://doi.org/10.15294/ aaj.v2i1.1136

Renders, A., \& Gaeremynck, A. (2012). Corporate governance, principal-principal agency conflicts, and firm value in european listed companies. Corporate Governance: An International Review, 20(2), 125-143. https://doi.org/10.1111/j.14678683.2011.00900.x

Prasetya, P. J., \& Gayatri. (2016). Pengaruh Ukuran Perusahaan Terhadap Manajemen Laba Dengan Pengungkapan Corporate Social Responsibility Sebagai Variabel Intervening. E-Jurnal Akuntansi Universitas Udayana, 511-538.

Prastuti, N. K., \& Budiasih, I. G. (2015). Pengaruh Good Corporate Governance Pada Nilai Perusahaan Dengan Moderasi Corporate Social Responsibility. E-Jurnal Akuntansi Universitas Udayana, 114-129.

Purbopangestu, H. W., \& Subowo. (2014). Pengaruh Good Corporate Governance Terhadap Nilai Perusahaan Dengan Corporate Social 
Responsibility Sebagai Variabel Intervening. Accounting Analysis Journal, 321-333.

Ramashar, W., \& Hasan, A. (2018). Pengaruh Kepemilikan Institusional dan Profitabilitas Terhadap Nilai Perusahaan Dengan Manajemen Laba Sebagai Variabel Intervening. Jurnal Akuntansi dan Ekonomika, 31-40.

Renders, A., \& Gaeremynck, A. (2012). Corporate governance, principal-principal agency conflicts, and firm value in european listed companies. Corporate Governance: An International Review, 20(2), 125-143. https://doi.org/10.1111/j.14678683.2011.00900.x

Sabatini, K., \& Sudana, I. P. (2019). Pengaruh Pengungkapan Corporate Social Responsibility pada Nilai Perusahaan dengan Manajemen Laba sebagai Variabel Moderasi. Jurnal Ilmiah Akuntansi dan 56 Bisnis, Vol. 14, No. 1, 56-69.

Sari, H. N., Astuti, T. P., \& Suseno, A. E. (2017). Pengaruh Manajemen Laba Dan Kebijakan Dividen Terhadap Nilai Perusahaan. Jurnal Akuntansi Kontemporer (JAKO) - vol 10 no 1, 46-55.

Sari, N. K., \& Widaninggar, N. (2020). Loan Loss Provision, Good Corporate Governance Dan Manajemen Laba Bank di Indonesia dan Malaysia. AFRE (Accounting and Financial Review), 3(1), 59-66. https://doi.org/10.26905/afr.v3i1.4555

Sari, P. M. (2016). Pengaruh Mekanisme Tata Kelola Perusahaan Terhadap Manajemen Laba Dengan Kesulitan Keuangan Sebagai Variabel Mediasi (Studi Empiris pada Perusahaan Manufaktur yang Terdaftar di BEI). Surabaya: Tesis Universitas Airlangga.

Schiper, K. (1989). Comentary Katherine on Earnings Management. Accounting Horison.

Shocker, A. D., \& Sethi, S. P. (1973). An approach to incorporating societal preferences in developing corporate action strategies. SUMMER I 1973 I VOL. XV I NO.4, 97-105.

Suryono, H., \& Prastiwi, A. (2011). Pengaruh Karakteristik Perusahaan dan Corporate Governance terhadap Praktik Pengungkapan Sustainability Report. Jurnal Simposium Nasional Akuntansi XIV Banda Aceh, 1-32.

Susanto, S., \& Christiawan, Y. J. (2016). Pengaruh Earnings Management Terhadap Firm Value. Business Accounting Review Vol. 4, No. 1, 205-216.
Suyanti, A. N., Rahmawati, \& Aryani, Y. A. (2010). Pengaruh Mekanisme Corporate Governance Terhadap Nilai Perusahaan Dengan Kualitas Laba Sebagai Variabel Intervening Pada Perusahaan Manufaktur Yang Terdaftar di Bursa Efek Indonesia Periode 2004-2007. Jurnal Ekonomi \& Bisnis, 173-183.

Theresia, M., \& Budi, A. B. (2020). Tata Kelola Perusahaan dan Pengakuan Pendapatan Prematur. AFRE Accounting and Financial Review, 3(1), 25-34.

Wardoyo, \& Veronica. (2013). Pengaruh Good Corporate Governance, Corporate Social Responsibility \& Kinerja Keuangan Terhadap Nilai Perusahaan. Jurnal Dinamika Manajemen, 132-149.

Widyasari, N. A., Suhadak, \& Husaini, A. (2015). Pengaruh Good Corporate Governance (GCG) dan Pengungkapan Corporate Social Responsibility (CSR) Terhadap Nilai Perusahaan. Jurnal Administrasi Bisnis (JAB) | Vol. 26 No. 1, 1-11.

Wulanda, M., \& Aziza, N. (2019). Pengaruh Corporate governance Terhadap Nilai Perusahaan Dan Manajemen Laba Sebagai Variabel Intervening Pada Perusahaan Manufaktur Go Public Di Indonesia. Jurnal Akuntansi Syariah, 83-108 